\title{
Muslim Women - Adapting Culture To The Modern Western World
}

Nadia Abgrab Noormohamed, (Email: nadia.abgrab@salve.edu), Salve Regina University

\begin{abstract}
Numerous messages of cross-cultural cooperation are shaping the global image of Muslim women worldwide - reaching communities with roots in hundreds of nations.
\end{abstract}

Key Words: Muslim Women, Muslim Culture, Islam

\section{TRADITIONAL VIEW OF MUSLIM WOMEN}

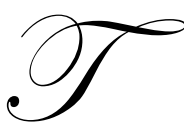

imes are changing for Muslim women... or are they? Numerous messages of cross-cultural cooperation are shaping the global image of Muslim women worldwide - reaching communities with roots in hundreds of nations. According to Sam Afridi from the Carnegie Corporation of New York, Muslims... reflect the diversity of the Islamic world and the diversity that... represent a rich mosaic of ethnic, racial, linguistic, tribal and national identities that stretch from Europe (2.987 percent of the total Muslim population) to Africa (27.23 percent of the total Muslim population) to Asia (69.336 percent of the total Muslim population) and beyond.

Islam places a high status on the responsibility of women. Muslim women play the role as the backbone and vital elements in the establishment of the society. (Basha) Historically, the role of the woman was to be a 'queen' residing in the home - to make it comfortable for her husband. Her sole duties were to take care of the children, cook, clean, and cater to her family. "The most important role for a woman is motherhood. This special role that Allah has created for her, affords her honor and respect in Islam." (Hamdam) In scores of less developed nations, this perceived 'slave-like behavior' is still the main mantra. However, volumes of Islamic history state that it was quite prevalent for women to play a dual role: called upon to guard their country in war while at the same time, continuing to work or even to maintain a household. Unfortunately, many of those established traditions are still ingrained in countless Muslim regions globally, and have a direct correlation to the culture of the area, and not to the religion practiced there.

\section{CHANGING VIEWS OF MUSLIM WOMEN GLOBALLY}

It has been reported that one out of five people around the world practices Islam. In New Zealand (a country of at least 3000 Muslims of European origin), for one week commencing on 8/8/06, "Mosques around the country held public open days... to enable people to drop in and discover more about Islam than they might read in the newspaper or see on television," said Ethnic Affairs Minister Mr. Carter. Since Islam regards men and women as being of the same essence created from a single soul, this 'Islamic Awareness Week' was a unique opportunity to learn about the beliefs, issues, and practices between the cultures and genders; lessening the chance for any future misunderstandings and/or conflicts.

Women Living Under Muslim Laws (an international Network established in London, United Kingdom in 1984), provides information, solidarity, and support for all women whose lives are shaped, conditioned, or governed by laws and customs derived from Islam. The Network (available in Arabic, English, and French) aims to create an awareness of Muslim laws and how they vary among cultures and builds bridges between women living in different Muslim communities. (http://www.wluml.org/) Another vehicle to offer mutual understanding among all faiths is the Islamic Institute for Human Rights: Muslim Women's Human Rights Program, an autonomous, non- 
governmental organization founded in Egypt to work on national and international levels. Their focus is to endorse equality for humankind, regardless of gender and that the oppression of Muslim women does not reflect the true value and message of Islam. (http://www.iifhr.com/)

Before women enter into the global village, a framework needs to be formulated to assist them in achieving acceptance within their societies. Women generally constitute a great underutilized asset for our economic development, and we need to ensure that we use this incredible resource as wisely as we use our oil or mineral resources - which are administered with the greatest of care. Muslims need to take a fresh look at the world and at their collective selves (Khan) and realize that future success lies in the ability of Muslim women to overcome past regressions and move forward to continue to progress on the world stage.

As Bernard Shaw, the great English liberal writer said: "In my opinion, Islam is the only religion, which has the stability to harmonize and exert its control over differing circumstances and changing ways of life, and to confront the diversities of the centuries." (Mutahhari) Leader of the American Muslim Mission, Imam W. Deen Mohammad, acknowledges the struggle. "We're a family of people under God." But it is human nature "that we tend to group together." Muslims "have the same problem that the world has, trying to learn from each other." (Moses).

Throughout the globe, the disabilities of Muslim women have been created by societies. Foreign disturbances and influences experienced by millions of Muslim women are causing many to become more involved in the workplace and in present-day society than ever before. Regardless of the chosen society, there is a shared philosophy which states - a society without the working power of women is an incomplete society.

\section{GLOBAL VIEWS OF TODAY'S MUSLIM WOMEN}

As viewed by Al Qaradawy, world citizens who wish to advance in the employment of women and increase their national economy, must look to the integrated civilization of the West. Since women represent half the population, it would be in the best interest of the family (increasing income to offset expenses of living) as well as for society (contact with people and life thereby polishing her personality), for women to work. "She should seriously consider the costs and benefits for herself, and the impact on her ability to fulfill her primary responsibilities, before taking on a job. There are many situations that may make it necessary for a woman to work, such as to assist with the financial needs of the family or to fulfill the needs of the society (doctors, midwives, teachers)." (Hamdam) The Qur'an says, "Hence, do not covet the bounties which God has bestowed more abundantly on some of you than on others. Men shall have a benefit from what they earn, and women shall have a benefit from what they earn. Ask, therefore, God [to give you] out of His bounty: behold, God has indeed full knowledge of everything." (4:32)

\section{Education For Muslim Women}

Islam has made it a duty on every Muslim male and female to gain knowledge, which is considered to be a superior act of worship in Islam. Education for female not only helps to further society, but also helps her to become a stronger and more confident mother and being. Preventing a Muslim woman from gaining an education is therefore un-Islamic. Acquiring knowledge enables Muslims to get a better perception and understanding of the world around us (Barkaati). The Qur'an says, "And for women are rights over men similar to those of men over women" (2:226). Prof. Abdur Rahman I. Doi, Professor and Director, Center for Islamic Legal Studies, Ahmadu Bello University, Zaira, Nigeria states that in Islam there is absolutely no difference between men and women as far as their relationship to Allah is concerned, as both are promised the same reward for good conduct and the same punishment for evil conduct.

In the 1990's, Muslim women in Lebanon only worked if they had to financially; it was a sign of social class and had nothing to do with women's rights or religion. There is greater integration of women into the private sector in this decade than in any time past. Many Muslim women are seeking careers in various medical fields, in education, in helping professions such as social work, counseling, psychology, psychiatry, and childcare. With the 
growth of technology and communications capabilities, there are unlimited opportunities for women to do some type of work or business from home such as secretarial and typing; writing, editing, publishing; computer work, etc., since many men are against the idea of women working outside the home after getting married. This would be an ideal situation that would eliminate many of the concerns that may arise for working women. (Hamdan)

According to Latiefah Akhmat, an Islamic counselor and social worker in Cape Town, South Africa, "These days, we see the emergence of more and more Islamic institutions, colleges, and so on, for men and for women. Things are changing, and Muslim women are becoming more educated in religion as well as in everyday life knowledge... Muslim women and men are beginning to realize that they can combine the two." Iranian space tourist Anousheh Ansari, a 40 year old telecommunications entrepreneur living in the United States, was the world's first paying female space tourist. Since Iranian women enjoy more political rights than women in some neighboring countries, she was able to begin her journey into space on September 25, 2006 aboard a Soyuz TMA-9 capsule from Baikonur, Kazakhastan; breaking barriers and becoming an inspiration to all Muslim women in this male-dominated country.

\section{Fashion For Muslim Women In The Workplace}

Muslim women all over the world are identified through the wearing of a hajab (the traditional headscarf of culture, elegance, heritage, and pride), from the bedouins to the boardrooms. Some may perceive these women to be submissive, soft-spoken, and not in good command of the English language; however "young women in Dubai (for example) are overturning a traditionally patriarchal culture to find their feet in the workplace." (Sharp) The wearing of a hajab is a symbol that depicts the decency of Muslim women and is worn as a respect to their religion, not to be shown as a political statement.

Ironically, "About 20 years ago, the situation surrounding Muslim women was very different to what we have now. If a woman worked, she was not allowed to wear hijab. Women were generally unable to demand their Islamic rights. So the women who worked were those who were forced to by necessity (poverty) or those who didn't mind compromising their Islamic values. This made the Muslim society, including men, feel aversion toward women working and leaving the house - it was seen as parallel to losing one's Islamic identity and values. As time passed, the gap between working Muslim women who compromised their Islamic identity and values, and women who stayed at home and wore hijab, widened." (Akhmat)

It is quite interesting to hear the views of people from the Western world that are outraged by Muslim girls wearing a headscarf, but at the same time tolerate women in skimpy clothes. Muslim women are not oppressed by this clothing item; in fact, many feel free from unwanted advances and sexual harassment that is faced by many Western women. When a Muslim woman covers herself, she places herself on a higher level by allowing men to see and respect her intellect, faith, and personality. The physical person is to play no role in social interaction.

'The new Islam woman' is portrayed as being educated, engaged in society and politics; ... she challenges the secular elite by representing an alternative modern image and identity. The central symbol for the modern Islamic woman is a certain kind of veil: Tesettür (the symbolism of the Tesettür veil is quite contradictory). The veil, with roots in the Ottoman elite's fashion, refers to values such as patriarchal hierarchy, gender segregation, and women's domestic role. Still other times the veil is simply a commercial fashion accessory (there are constantly changing patterns and colors, special fashion shows, and shops) associating the bearer with an active, urban, and modern Islamic lifestyle. As a uniform and symbol of social mobility, the Tesettür veil unites people across class and political motivation; as a fashion accessory it differentiates between those who can afford to follow the latest trends and buy quality materials, and those who cannot afford to. (Kristiansen)

Many modern Muslim women now have the opportunity to pursue a three-year professional fashion design program in drafting, computer-aided design, marketing, live drawing, fashion, culture, textiles, and communication. The Paris-based Ecole de Mode International (ESMOD) offers master's programs in fashion design and business administration in France, Germany, Norway, China, Japan, South Korea, Indonesia, Lebanon, Syria, Tunisia, Brazil in collaboration with the Fashion Design Institute in Riyadh, Saudi Arabia. ESMOD provides young women with 
the opportunity to create their own designs that are suitable to Muslim culture and identity, a much needed educational opportunity. "It is necessary to break out of the patriarchal, traditionalist, isolationist mentality concerning women and encourage and facilitate Muslim girls to be educated in every way-Islam and everyday knowledge." (Akhmat) Many of these students explore careers as retailers, tailors, merchandising assistants, as well as fashion designers. (Fatany)

Shainin Hudda who established SoulDaisy Clothing Designs in 2000, is a perfect example of the educated Muslim woman. Born in 1969 in Kampala, Uganda in Africa, she immigrated to Canada as a child. There she received her diploma in fashion design and clothing technology as well as a Bachelor's degree in business administration from the Art Institute of Vancouver. After completing a major in marketing and communications and extensive work experience for a local designer, she created a high-quality contemporary, urban ready-to-wear clothing collection for modern women with individuality. Her innovative detailing and styles are available twice per year and are sold in specialty shops and swanky boutiques across North America and worldwide direct through the website at www.souldaisy.com.

"At the same time, ...countries are forced to change to compete globally, let's remember that fashions may have to change somewhat to enable both women and men to be effective workers in a variety of situations - not in the name of promoting Western garb, but in promoting economic success for our nation." (Fatany) "But there remain issues for women in Islam... Some... balk at traditional Islamic dress, which requires women to cover their hair and wear loose, enveloping garments." (Paulson) "At the same time, we wanted to acknowledge where we are in the West." (Q-News)

\section{LIFE FOR MUSLIM WOMEN IN THE UNITED STATES}

Fostering a better understanding of Islam is not simply a challenge for Muslims, but a challenge for all Americans. Islam, after all, can no longer be considered a non-Western religion and Muslims are no longer "them." Muslims are "us" and is the fastest growing religion in the United States. Democratic politician Robert F. Kennedy, then United States Attorney General, said in his "Extremism, Left and Right," pt. 3, in The Pursuit of Justice in 1964, "Ultimately, America's answer to the intolerant man is diversity, the very diversity which our heritage of religious freedom has inspired." The religious beliefs, social customs, dress, language, music, family, structure, traditions of hospitality are only some of the multiple dimensions assimilated into the values of mainstream American society.

According to Rifkin, "the American Muslim community is more affluent and educated than anywhere else. That will lead to greater development of Islamic thought here to a degree that I think in the future the Muslims of America will be influencing the leaders of Muslim nations more than the other way around." More recently, in 2001, the Boston Globe noted that, by redefining their role in culture and society, American Muslim women may have an impact on Muslims throughout the world. As the paper reports: 'Unfortunately, the way Islam is practiced currently in some countries is not ideal,' said [one Massachusetts woman]. 'A lot of countries are looking to see how we practice it here, and we have the potential to be a really strong role model for... women in other countries.' (Paulson)

American Muslims who follow Prophet Muhammad's (peace be upon him) doctrine of 'tolerance and equality of others messages' see themselves as pioneers contributing to the development of society. Some young Muslim women may be perceived as radical and/or ambitious, yet they are much better educated than their mothers and are using this as a springboard for them to play a much wider role in society. In the 21st century, American Muslim women are now finding ways to make it work. As Smith notes, "The Qur'an is cited as being fully egalitarian in its treatment of men and women... Muslims generally insist that this equality represents a great improvement over the circumstance of women before Islam and that the Qur'an is a remarkably equitable document in comparison with the sacred scriptures of other religious traditions." Social consciousness, justice, and divine harmony are messages continually reiterated throughout the faith. "In order to understand what Islam has established for woman... Islam has given woman rights and privileges... The rights and responsibilities of a woman are equal to those of a man but they are not necessarily identical with them. Equality and sameness are two quite 
different things... Equality is desirable, just and fair; but sameness is not. There is no ground to assume that she is less important than he just because her rights are not identically the same as his... The fact that Islam gives her equal rights - but not identical - shows that it takes her into due consideration, acknowledges her, and recognizes her independent personality." (Sayed)

The irony of Islam in America is that except for a few instances, we are thoroughly integrated secularly and civilly but grossly separated and dysfunctional religiously. (Ahmad) Many American Muslims fear that being involved will mean being misunderstood or, worse, becoming a victim of a campaign to demonize their religion or distort their views. Editor Greg Noakes, an American Muslim commentator, observes that many Americans, Muslims, and non-Muslims alike, believe another major barrier to greater understanding of Islam lies in the portrayal and images of Muslims in the media. "For the most part, American media coverage of Muslims and events in the Muslim world concentrates on the sensational... in the hunt for sensationalism the media pass over the exciting variety of interpretation and expression among Muslims who often profess very different ideas and attitudes while still remaining within the Islamic community." These culturally based-misinterpretations from "both Muslims and non-Muslims label the systematic distortion of Islam as 'Islamophobia,' a fear of everything Islamic.” (Smith)

American Muslims, "continue to face dehumanization and a growing trend of Islamophobia," said Abdul Malik Mujahid, chairman of the Council of Islamic Organizations of Greater Chicago. In a 3-day meeting held on 9/1-3/06 in Rosemont, IL that drew nearly 40,000 Muslims from Canada and the United States, Ingrid Mattson, the newly elected and the first woman president of the Islamic Society of North America, called President George W. Bush's recasting of the war on terror as a "war against Islamic fascism", inaccurate and not helpful to people of her faith. Labeling terrorism as "Islamic" only adds to a misunderstanding of the religion. As an alternative to "Islamic fascism,' Mattson suggested the words 'terrorism, crime, violence,' adding that she and other Muslims don't understand why the label 'Islamic' is included when Bush and other leaders talk about terrorism." Sharing similar thoughts, Akhmat believes that, "nowadays, if a Muslim woman practices Islam — she prays, fasts, wears hijab, and so on-she is sometimes seen as a fundamentalist and perhaps a terrorist, which reflects the general misunderstanding of people regarding Islam." Hoping to dispel these stereotypes and breakdown cultural prejudices, Deputy Secretary of Defense Gordon England called on Muslim Americans to spread to the world the word about freedom, citing the success of Muslim businesspeople and professionals in the United States.

AZIZAH magazine, created by Tayyibah Taylor and Marlina Soerakoesoemah from Atlanta, Georgia, reflects the experiences and perspectives of Muslim women living in North American society. It is the authentic voice of contemporary Muslim women - sharing positive life experiences of intelligent, confident, and energetic Muslim women who are blazing trails with their faith in full view. It speaks of countless young women who feel blessed to be Muslim and are eager to use their talents... to springboard further in their communities. These women are empowered by their faith and acknowledge Allah for their success. In demonstrating remarkable courage and good judgment, Muslim women are raising the bar and setting high standards while taking risks and pushing through boundaries. AZIZAH teaches Muslim women not to be myopic, but to face life altering events such as aids, cancer, pregnancy, etc. - by encouraging them to know their bodies (not to be ashamed) and to seek medical attention early in the detection process. Additionally, calling upon their faith for extra healing blessings has increased the number of women who are survivors.

One young Temple University junior who did not fear a challenge to dispel misperceptions regarding her background is Aziza Hassan, a world-class fencing expert. Despite the wave of 'Islamophobia' attacks, extremism, and stereotyping; she continued to make her classmates, community, and family proud of her accomplishments. Reaching world-class status for her division in 2003, Ms. Hassan humbly displayed her national heritage and culture. She is currently the assistant coach of the women's fencing team at Stevens Institute of Technology in New Jersey and still fences for the prestigious Peter Westbrook Foundation. The Dallas Morning News reported: "Muslim women are forming national groups to provide them with a platform and an organized voice. They're...writing papers and booklets... teaching Islamic Women's Studies at universities...starting battered women's shelters and opening a home for elderly Muslim women...A few are even gingerly calling themselves feminists as they scrutinize the Koran and rediscover it as a scripture that liberates women." (Caldwell) 


\section{Muslim Women In United States Politics}

More American Muslims were elected to public office in 2004 than in previous years. The American Muslim women voter lags behind their male counterpart by a ratio of 1:2. However, in data collected by the Council on American Islamic Relations (CAIR) and the American Muslim Alliance (a civic education and leadership training organization with 101 chapters nationwide), young Muslim women ages $18-29$ years old were observed voting in a larger percentage than young Muslim male voters (57 percent female voters versus 43 percent male voters). Additionally, this target audience produced larger national percentages than the United States average (26 percent for Muslim voters versus 17 percent nationally). Ferial Masry, a Muslim woman Democrat from California running for state assembly, joined the race late as a write-in candidate but won the primary elections and received 41 percent of the popular vote in the general election. Ms. Yaphette El Amin, of St. Louis, Missouri who ran for Missouri State Assembly was the first Muslim women to win an election since September 11, 2001. Her slogan, "Leadership you can trust," earned her 56 percent of the votes.

There are approximately 100 Muslims who ran for various public offices in 2004, a modest improvement over less than 70 Muslim candidates in 2002, but still far less than the all-time high of 700 candidates in 2000. According to a number of national post election surveys, there is still a significant amount of work to be done by national organizations to educate the senior citizens in the Muslim community (only 11 percent of Muslim voters over 60 years of age versus the national percentage of 22).

If we are to project women in political and leadership positions, they should be educated on government regulations and made aware of the accepted social conduct and the Muslim perspective in the new emerging political scene among nations. In order to do that, however, we need to develop a Muslim perspective that truly reflects the teachings of the Prophet (peace be upon him) and leaves behind any cultural add-ons that spawn intolerance, hatred, or unnecessary restrictions on women. "As women become 'workers' struggling to prove themselves in their position in the business world, men are beginning to sense an uncomfortable feeling of rivalry from the "weaker sex'. For.... man it can get scary. They're doing a very good job and they're giving us big competition," says Fahad Qahtani, a 25 year old informational technology student in Dubai. According to Ayesha Ahmed, a reporter from Azizah Magazine, Muslim women are even beginning to enter the male-dominated field of engineering -- blazing a trail for all women.

\section{CONCLUSION}

The Muslim community is here to stay - their future is in America, the most ethnically diverse community of Muslims anywhere in the world. As such, it is vital that we as a nation seek a more balanced understanding of the complexities, challenges, and opportunities inherent in the emergence of the American Muslim people. To the extent that we can gain greater awareness and confront these issues, their participation will grow and democratic institutions will be strengthened. On the other hand, if American Muslims are neglected or misunderstood, our society as a whole will lose out. (Afridi)

Positive changes in attitude towards Muslim women will not occur overnight or within a single generation, it is a constant state of evolution. The empowerment of Muslim women involves winning the hearts and minds of the general public through the understanding of foreign influences and cultural patterns. As Vartan Gregorian, President of Carnegie Corporation of New York, said, "Tolerance is not enough - we need acceptance. Without understanding there's not going to be acceptance, and we have a long way to go." It took Western women more than 100 years of multifaceted differences and generational tensions before achieving what they have today.

Overcoming the many struggles and challenges, and having an identity that is deeply rooted in linguistic differences, political concerns, and religious histories makes us all aware of our membership in the world. Furthering our knowledge of the world requires nations to know one another. As Muslim women emerge as educated, talented individuals, they are beginning to create new images, paths, and identities for themselves in the evolving global marketplace. It is said that Islam is a melting pot for all races and ethnic identities; therefore accepting cultural cues is crucial for the stability, success, and sustenance of all Muslim women. 


\section{REFERENCES}

1. Afridi, Sam. Muslims in America: Identity, Diversity and the Challenge of Understanding 12 November, 2003. Carnegie Corporation of New York. http://www.carnegie.org/pdf/muslims.pdf

2. Ahmad, Abu Laith Luqman, Imam. Normalizing Islam in America IslamiCity. 18 July 2004

3. Akhmat, Latiefah. To Be a Woman - Confronting the Obstacles: Experience of a Muslim Woman Living in South Africa 04 May, 2005. IslamOnline.net.

http://www.islamonline.net/English/In_Depth/ToBeaWoman/

4. Al Qaradawy,Yusuf Dr. The Status Of Women In Islam http://www.witness-pioneer.org/vil/Books/Q_WI/

5. American Muslim Perspective. Arab and Muslim Stereotyping in American Popular Culture 28 December, 2004. Executive Editor: Abdus Sattar Ghazali. http://www.amperspective.com

6. Barkaati, Sayyid Shah Ale'Rasool Nazmi al-Husaini. Gateway to Heaven http://www.raza.co.za/Books/Gateway to Heaven.htm

7. Basha, Sister Nihaya. What is the Role of Muslim Women? 17th Annual Conference of the Federation of Australian Muslim Students and Youth at the Royal Melbourne Institute of Technology. 12 July, 1998. http://members.iinet.net.

8. Caldwell, Deborah Kovach. Muslim Women Work to Alter Stereotypes, Dallas Morning News. 8/4/96. p. $1 \mathrm{~A}$

9. Doi, Abdur Rahman I. Women in the Quran and the Sunna. Center for Islamic Legal Studies, Ahmadu Bello University, Zaira, Nigeria. Mei 10, 2006.

10. Fatany, Samar. A Muslim Identity in Tune With the World. Arab News. 6 June, 2006 (10, Jumada al-Ula, 1427)

11. Hamdan, Aisha Dr. Employment Concerns for Working Muslim Women. 24 August, 2002. Islamweb.net - Jumuah - Volume 12, Issue: 11 http://www.islamweb.net/ver2/archive/article.php?lang=E\&id=26927

12. Khan, Muqtedar. Islam in America: Muslim Democrats Triumphs over Muslim Nationalists. Washington Report on Middle East Affairs, 13 May, 2000. Volume XX, No.2, p.82

13. Kristiansen, Nina. The modern Islamic Woman. 30 January, 2004 http://kilden.forskningsradet.no/c18375/

14. Moses, Paul. Study Finds U.S. Muslims More Diverse, Newsday, 4/27/01, p. A52

15. Mutahhari, Ayatullah Murtada. The Rights of Women in Islam, Part Four: Islam and Modernity - The exigencies of the age. World Organization For Islamic Services Publishing, Tehran, Iran. 1980. http://www.alislam.org/

16. $\quad$ NBC5.com - News - Muslim Group's Head Criticizes Bush Rhetoric. 9/1/06. http://www.nbc5.com/news/9779740

17. Noakes, Greg. Muslims on the Americanization Path? Muslims and the American Press. New York: Oxford University Press, 2000), p. 286

18. Paulson, Michael. The Draw of Islam: Perplexed or Unfulfilled by their Parents' Faiths, A Growing Number of Women are Becoming Muslims, Boston Globe. 13 May, 2001, p. B1

19. Q-News. Grateful Threads. November 2003, Ramadan 1424, No.351. pp.42-43.

20. Rifkin, Ira. Islam's Outlook Brighter, Ventura County Star. 11 December 1999, p. D1

21. Sayed. Egypt. The Status of Woman in Islam Excerpted, with slight modifications, from Islam in Focus by Hammuda `Abdul-Ati. http://www.islamonline.net/

22. Sharp, Heather. Dubai women storm world of work. 8/5/05. http://news.bbc.co.uk/1/low/world/middle east/

23. Sharp, Heather. Middle East youth: A generation in flux. 7/29/05. http://news.bbc.co.uk/1/low/world/middle_east

24. Smith, Jane. Islam in America. New York Columbia University Press. 1999. p. 106, 173 
NOTES 